\title{
Effect of Immobilization Method on the Growth of Chlorella vulgaris and Fatty Acid Profile for Biodiesel Production
}

\author{
Nur Hanani Rushan, Nur Hidayah Mat Yasin*, Noor Raihana Abu Sepian, \\ Farhan Mohd Said, and Nurafifah Izzati Shafei
}

Faculty of Chemical and Natural Resources Engineering, Universiti Malaysia Pahang,

Lebuhraya Tun Razak 26300, Gambang, Pahang, Malaysia

\section{* Corresponding author:}

tel: $+609-5492853$

email: hidayahyassin@ump.edu.my

Received: August 3, 2018

Accepted: November 14, 2018

DOI: $10.22146 / \mathrm{ijc} .39800$

\begin{abstract}
The aim of this research is to study the immobilization effect on growth cell of microalgae Chlorella vulgaris. The comparison of lipid production between immobilized microalgae and free cell culture was also studied, and the fatty acid methyl ester for biodiesel production was identified in this research. Four important steps were done in this research, which included microalgae cultivation, harvesting method by immobilization, lipid extraction, and transesterification of oil. In the immobilization method, the combination of a matrix system of sodium alginate and sodium carboxymethylcellulose (SA and CMC) gave the highest number of cells of microalgae after the $9^{\text {th }}$ day of the cultivation process. However, the immobilized microalgae matrix system of SA at volumetric ratio of 0.3:1 showed better results for extraction of oil, attaining an oil yield percentage of $46 \%$ compared with other matrix systems studied; $S A$ $+C A+C M C$ (43.00\%), SA + CA (41.19\%), SA + CMC (40.38\%) and free cell culture (42.57\%). Furthermore, the fatty acids methyl ester profile of the extracted oil showed high potential for biodiesel production. The results proved that the immobilization of microalgae had improved the oil yield and fatty acid composition as compared to the free cell culture, which may have useful application for the biofuel industry.
\end{abstract}

Keywords: microalgae; Chlorella vulgaris; immobilized; fatty acids; lipids

\section{- INTRODUCTION}

Microalgae are known as phytoplankton by biologists and have a high potential for use in various fields of application, as well as a significant role in higher production of biomass and lipid [1-3]. As a fact, microalgae have a simple cell division cycle and can grow in the sea or brackish water. Besides that, these organisms have high photosynthetic efficiency capable of producing approximately $40 \%$ of photosynthesis [4]. There are broad functionality of microalgae extends to various fields, especially in biotechnology such as for aquaculture, food production, cosmetic and pharmaceutical industries [57]. Each microalgae species has its own characteristics such as size, shapes, densities, and properties encountered by cell surface [8]. Chlorella sp. grows in lakes and freshwater ponds and is known as single-cell microalgae. This species is among the microalgae species capable in producing lipids and oils for use in biodiesel processing. Specifically, the microalgae Chlorella vulgaris is known for its robustness, in conjunction with being one of the fastest growing species and easily cultivated [9].

Another challenge when using microalgae as a source of biodiesel is microalgae harvesting, which accounts to as much as $20-30 \%$ of the production costs [10]. The harvesting method is costly as well as problematic due to the minute size of the microalgae cell that can range from 2 to $200 \mu \mathrm{m}$. During the dewatering process, large volumes of dilute cultures are needed (around $<0.5 \mathrm{~kg} \mathrm{~m}^{-3}$ dry biomass) to get sufficient biomass [2,11]. Technologies for harvesting microalgae have been recognized as major contributors for biofuel production [12], in which competent harvesting technologies are needed for maximizing quantity of biomass to be harvested [11]. 
Methods for harvesting microalgae to recover the produced lipid encompass the use of centrifugation [13], immobilization [6], filtration [14], coagulation [15], and sedimentation [16]. Among the methods, immobilization technology appears to be a more unusual technique for microalgae harvesting as compared to conventional methods. Conventional methods of harvesting lipid from microalgae used by many researchers typically rely on centrifugation and filtration. In contrast, the method of microalgae immobilization offers numerous advantages such as requiring lesser energy and easier to handle, especially when handling a large scale microalgae culture. However, there are several disadvantages to this method that must be overcome such as bead rupture, beads dissolution, and limitation of mass transfer [11], associated with the restrained free movement of microalgae in an entrapped matrix. It allows the cell to continue to grow in the matrix [17-18].

Sodium alginate is usually used among the preferred matrix immobilization due to its low toxicity. Also, the small alginate beads are highly transparent and, the alginate gel is prepared under mild conditions $[11,19]$. Correspondingly, sodium carboxymethylcellulose is highly permeable matrix due to their height water content, which is practical and advantageous for biotechnological uses. The enhanced degradability of sodium carboxymethylcellulose makes it a potential candidate for various uses, particularly as a replacement of the polymer of petroleum origin [20].

Generally, growth rates of immobilized cells are lower than that of the free cell culture. However, the opposite trend was found, in which the maximum growth rate is observed for both the free and immobilized cell cultures during the exponential phase. Several studies have shown that a higher final yield was achieved for alginate immobilized cells after 15 days incubation in a growth medium as compared to free cell cultures [21]. Hence, the aim of this research is to study the immobilization effect on the growth of microalgae Chlorella vulgaris. Additionally, lipid production by the immobilized microalgae cells was compared with the free cell culture, and fatty acid methyl ester for biodiesel production was identified.

\section{- EXPERIMENTAL SECTION}

\section{Materials}

Microalgae strain used in this research was Chlorella vulgaris obtained from the Culture Collection of Algae and Protozoa (CCAP), Scottish Marine Institute, United Kingdom. Microalgae C. vulgaris was cultured in Bold Basal Medium (BBM) with 3-fold nitrogen and vitamins. Four types of BBM used in this study were BBM (I), BBM (II), BBM (III) and BBM (IV). The chemical compounds of BBM (I) contained $75.0 \mathrm{~g}$ of $\mathrm{NaNO}_{3}, 2.50 \mathrm{~g}$ of $\mathrm{CaCl}_{2} \cdot 2 \mathrm{H}_{2} \mathrm{O}, 7.50 \mathrm{~g}$ of $\mathrm{MgSO}_{4} \cdot 7 \mathrm{H}_{2} \mathrm{O}$, $7.5 \mathrm{~g}$ of $\mathrm{K}_{2} \mathrm{HPO}_{4} \cdot 3 \mathrm{H}_{2} \mathrm{O}, 17.5 \mathrm{~g}$ of $\mathrm{KH}_{2} \mathrm{PO}_{4}$, and $2.5 \mathrm{~g}$ of $\mathrm{NaCl}$. The chemical compounds of BBM (II) contained $0.75 \mathrm{~g}$ of $\mathrm{Na}_{2} \mathrm{EDTA}, 97.0 \mathrm{mg}$ of $\mathrm{FeCl}_{3} \cdot 6 \mathrm{H}_{2} \mathrm{O}, 41.0 \mathrm{mg}$ of $\mathrm{MnCl}_{2} \cdot 4 \mathrm{H}_{2} \mathrm{O}, 5.0 \mathrm{mg}$ of $\mathrm{ZnCl}_{2}, 2.0 \mathrm{mg}$ of $\mathrm{CoCl}_{2} \cdot 6 \mathrm{H}_{2} \mathrm{O}$, and $4.0 \mathrm{mg}$ of $\mathrm{NaMoO}_{4} \cdot 2 \mathrm{H}_{2} \mathrm{O}$. BBM (III) and BBM (IV) comprised of $0.12 \mathrm{~g}$ of vitamin $\mathrm{B}_{1}$ (thiamin hydrochloride) and $0.10 \mathrm{~g}$ of vitamin $\mathrm{B}_{12}$ (cyanocobalamin), respectively.

Four chemicals used for the oil extraction and transesterification processes were methanol $\left(\mathrm{CH}_{3} \mathrm{OH}_{4}\right.$, chloroform $\left(\mathrm{CHCl}_{3}\right)$, hexane $\left(\mathrm{C}_{6} \mathrm{H}_{14}\right)$ and hydrochloric acid $(\mathrm{HCl})$. Chemicals used for the immobilization studies were calcium chloride $\left(\mathrm{CaCl}_{2}\right)$, sodium carbonate anhydrous $\left(\mathrm{Na}_{2} \mathrm{CO}_{3}\right)$, sodium alginate, calcium alginate, and sodium carboxymethylcellulose. All the chemicals were purchased from Merck (Germany), Sigma-Aldrich (USA), Oxoid (UK) and R\&M Chemical (UK).

\section{Instrumentation}

The absorbance of medium culture was determined using UV-vis spectrophotometer (Varian Cary 50 Probe, Australia), to measure the cells of immobilized microalgae. This experiment also used gas chromatography-mass spectrometry (GC-MS Agilent 7890 A) to analyze the fatty acid methyl ester (FAME).

\section{Procedure}

\section{Media preparation}

BBM (I) and BBM (II) were freshly prepared and autoclaved for $15 \mathrm{~min}$ at $121{ }^{\circ} \mathrm{C}$ to avoid any contamination. The most concentrated solution was 
BBM (IV). Therefore, $1 \mathrm{~mL}$ of the concentrated solution was added to $99 \mathrm{~mL}$ of sterilized distilled water to make up a $100 \mathrm{~mL}$ volume of new BBM (IV). After that, BBM (III) and BBM (IV) were transferred slowly into a $250 \mathrm{~mL}$ of Schott bottle using a sterilized syringe and was filtersterilized through a $0.2 \mu \mathrm{m}$ membrane. The culture medium was prepared by adding $10.0 \mathrm{~mL}$ of BBM (I), 6.0 $\mathrm{mL}$ of BBM (II), and $1.0 \mathrm{~mL}$ of each of BBM (III) and BBM (IV) to $1 \mathrm{~L}$ of sterile distilled water [15]. Then, the culture medium was prepared.

\section{Preparation of free cell culture for Chlorella vulgaris}

The free cell culture of $C$. vulgaris was seeded into 2 L Schott bottle filled with sterile distilled water containing BBM (I) until BBM (IV) at a temperature of $25^{\circ} \mathrm{C}$. Two fluorescent lamps (Philip TL-D $36 \mathrm{~W} / 865$, light output $3050 \mathrm{~lm}$ ) were used to expose the culture to continuous illumination. The culture system was subjected to continuous aeration at constant pressure for 10 days [15].

\section{Harvesting of free cell culture}

The harvesting method for the free cell culture was conducted by centrifugation performed at $8000 \mathrm{rpm}$ for $10 \mathrm{~min}$. The clear solution was discarded to obtain the biomass. Then, the microalgae biomass was rinsed with deionized water and lyophilized overnight (SGD Serail Argenteuil, France) to measure the cell dried weight [15].

\section{Preparation of immobilized microalgae beads}

For the preparation of immobilized beads, $2.5 \mathrm{~mL}$ of BBM (I), $1.5 \mathrm{~mL} \mathrm{BBM} \mathrm{(II),} \mathrm{and} \mathrm{every} 0.25 \mathrm{~mL}$ of BBM (III) and BBM (IV) were added to a conical flask filled with 250 $\mathrm{mL}$ of sterile distilled water (DW). Sodium alginate (SA) solution of $2 \%(\mathrm{w} / \mathrm{v})$ was prepared as a control. Then, the solution was mixed with $10 \mathrm{~mL}$ of microalgae solution at a different volumetric ratio of $0.3: 1$ and 1:1. The mixture was stirred thoroughly until all SA was completely dissolved. After that, $2 \mathrm{w} / \mathrm{v} \%$ of $\mathrm{CaCl}_{2}$ solution was prepared by adding $0.6 \mathrm{~g}$ of $\mathrm{CaCl}_{2}$ into $30 \mathrm{~mL}$ sterile distilled water [17]. The immobilized beads were then prepared by dropwise addition of microalgae solution into $\mathrm{CaCl}_{2}$ solution using a pipette. Beads were formed directly and left for $1 \mathrm{~h}$ to harden at room temperature and stabilized their formation. The formed beads were filtered through a sieve and rinsed 3 times with sterile distilled water. The hardened beads were transferred into a $250 \mathrm{~mL}$ conical flask containing $250 \mathrm{~mL}$ of growth medium for the subsequent 10-day cultivation duration. The culture was aerated continuously by bubbling air into the system at a constant pressure [17,22]. The above methods were repeated with different combinations of matrix systems. The combinations resulted from a $2 \%$ $(w / v)$ of each matrix being mixed at different ratios, comprising the 1:1 ratio of SA and CA, 1:1 of SA and CMC and 1:1:2 of the SA, CA and CMC.

\section{Determination of microalgae biomass and growth curve of microalgae}

Five immobilized microalgae beads were taken every day and solubilized in $2 \mathrm{~mL}$ of sodium carbonate anhydrous solution to determine the number of cells grown inside the beads. The samples were taken until day 10 of cultivation and measured at $600 \mathrm{~nm}$ using a UV-Vis spectrophotometer (Varian Cary 50 Probe, Australia). In order to estimate the existing population of C. vulgaris, a calibration curve was first established using known numbers of $C$. vulgaris cells, determined using a hemocytometer equipped with an optical microscope. Both methods were utilized simultaneously throughout the cultivation process and verified frequently. The growth performance of the microalgae was determined from the growth curve of immobilized cell and was compared with different matrices at a volume ratio of $0.3: 1$ and 1:1. All experiments were carried out in triplicate [22].

\section{Lipid extraction}

Lipid was extracted from the microalgae biomass using the solvent extraction method. Microalgae biomass $(0.07 \mathrm{~g})$ from the immobilization systems were extracted to determine the lipid contents in the microalgae. The biomass was mixed with $5.5 \mathrm{~mL}$ of distilled water in a test tube and sonicated (sonicator Fisher brand FB15051) for 5 min to lyse the cells. Then, $8 \mathrm{~mL}$ of methanol and $4 \mathrm{~mL}$ of chloroform were added to the microalgae biomass for the extraction process, and the process was carried out at $65^{\circ} \mathrm{C}$ for $6 \mathrm{~h}$. The resultant mixture was centrifuged at $5000 \mathrm{rpm}$ for $2 \mathrm{~min}$, and the bottom layer was collected. Nitrogen gas flow was used

Nur Hanani Rushan et al. 
to evaporate the solvent, and only the lipids remain. The weight of the lipids was measured gravimetrically [22].

\section{Transesterification method}

An acid-catalyzed transesterification process was used in this research. Since microalgae lipid has a high acid content, so hydrochloric acid was chosen as the acid catalyst. The mixture consists of $4 \mathrm{~mL}$ of hexane, $4.25 \mathrm{~mL}$ of methanol, and $0.215 \mathrm{~mL}$ of hydrochloric acid, and the solution was heated on a hot plate at $85^{\circ} \mathrm{C}$. After $2 \mathrm{~h}$, the solution was centrifuged at $3000 \mathrm{rpm}$ for $2 \mathrm{~min}$ to form liquid two layers, in which the upper layer consisted of fatty acid methyl ester and the lower layer contained glycerol [22].

\section{Analysis of fatty acid methyl ester}

Fatty acid methyl ester (FAMEs) analysis was performed using a gas chromatography-mass spectrometry (GC-MS Agilent 7890 A). The samples were injected and vaporized and carried onto the capillary column ( $30 \mathrm{~m}$ length and $0.25 \mathrm{~m}$ ). The initial temperature was $40^{\circ} \mathrm{C}$ and was held for $5 \mathrm{~min}$ before the temperature was raised to $300{ }^{\circ} \mathrm{C}$ at $10{ }^{\circ} \mathrm{C} / \mathrm{min}$. The injector temperature was set at $260^{\circ} \mathrm{C}$ for another $3 \mathrm{~min}$. The fatty acid composition in the microalgae lipid was observed, and the result was recorded [22].

\section{- RESULTS AND DISCUSSION}

\section{Growth Performance of Immobilized Microalgae Using Sodium Alginate}

Fig. 1 shows the growth curve of immobilized microalgae in sodium alginate (SA) over 10 days of cultivation. The immobilization method was carried out using different volume ratios of SA to microalgae (SA:Mc), which are $0.3: 1$ and 1:1. At the beginning of the cultivation, the number of cells of in the immobilized microalgae system for the volumetric ratio 0.3:1 was higher compared to the 1:1 ratio, until the day 7 of cultivation. However, cell numbers began to decrease at day 8 of cultivation. The highest number of cells was observed on day $9\left(8.30 \times 10^{9}\right.$ cells $\left./ \mathrm{mL}\right)$ for the volume ratio of $1: 1$, was reduced to $7.05 \times 10^{9}$ cells $/ \mathrm{mL}$ at day 10 . This was probably due to the shrinking of microalgae beads (volume ratio of 1:1) during the cultivation process

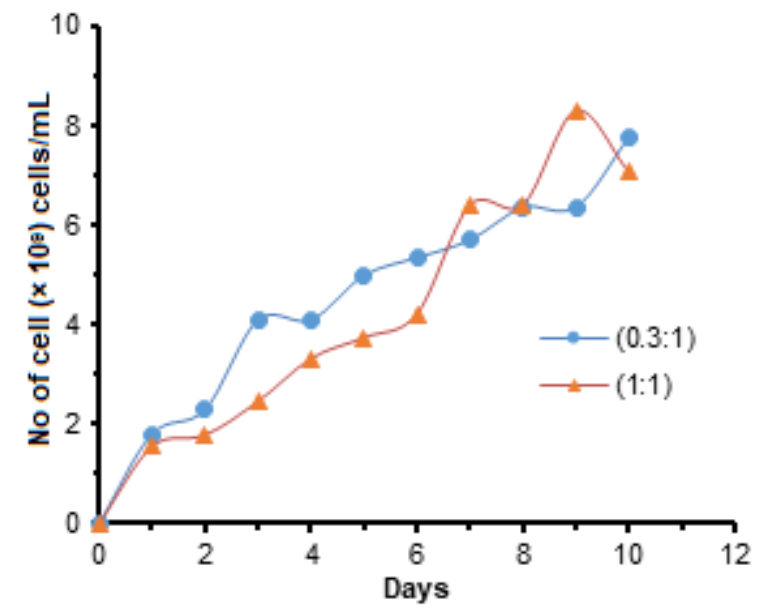

Fig 1. Growth performance of immobilized microalgae at different ratio of SA

compared to microalgae beads of volume ratio of 0.3:1 [17]. This result was in line with Abu Sepian et al. [22] that reported the highest number of cells of immobilized microalgae C. vulgaris was obtained using SA of volumetric ratio of 1:1. The authors stated that it was probably due to the large surface area of the beads that supported the growth of microalgae cells prepared at a volume ratio of 1:1 [22]. Meanwhile, the immobilized microalgae system prepared using a volume ratio of $0.3: 1$ showed a lower cell number $\left(6.36 \times 10^{9}\right.$ cells $\left./ \mathrm{mL}\right)$ as compared to a volumetric ratio of 1:1 at day 9 . Though, the number of cells continued to increase at day 10 of cultivation.

As reported by the previous researchers, the membrane thickness is an important criterion since it influences the mass transfer of nutrients and $\mathrm{CO}_{2}$ availability for aerobic microalgae from the medium to the matrix [22-23]. Nevertheless, based on a report by Abu Sepian et al. [22], the membrane thickness is an insignificant factor influencing the mass transfer of microalgae cells between the matrix. This was shown to be quite true based on the results of the immobilized microalgae systems from the volumetric ratio of $0.3: 1$ and 1:1. According to Moreno-Garido [6], for immobilized microalgae in SA, the membrane thickness is unimportant to the microalgae cell between the matrix due to high transparency and high permeability of the SA matrix. SA immobilized matrix can provide a suitable 
environment for the growth of immobilized microalgae cell despite the thick membrane $[6,22]$. Thus, based on the obtained results, the suitable volumetric ratio of immobilized microalgae growing in SA was a ratio of 1:1 for 9 days of cultivation.

\section{Growth Performance of Immobilized Microalgae Using a Combination of Sodium Alginate and Calcium Alginate}

Fig. 2 shows that the growth curve of immobilized microalgae using the combination of SA and calcium alginate (CA) to microalgae (SA \& CA:Mc) with the volume ratio of $0.3: 1$ and $1: 1$. As can be seen, the number of cells of volume ratio $0.3: 1$ was lesser compared to $1: 1$ from day 1 to day 3, but it started to increase from day 3 till day 7. However, the number of cells for the volume ratio of $1: 1$ was higher $\left(7.75 \times 10^{9}\right.$ cells $\left./ \mathrm{mL}\right)$ as compared to that of ratio $0.3: 1\left(7.71 \times 10^{9}\right.$ cells $\left./ \mathrm{mL}\right)$ starting from day 7 till day 9 of cultivation. It was observed that the different number of cells between the volume ratio 0.3:1 and 1:1 was small $\left(0.04 \times 10^{9}\right.$ cells $\left./ \mathrm{mL}\right)$. Thus, it can be concluded that the volumetric ratio of $0.3: 1$ and $1: 1$ for the combination of SA and CA gave the same effect to the growth of microalgae cells in the matrix.

The water-insoluble characteristic of CA may prevent the diffusion of nutrients in the matrix so that when CA was combined with SA as a matrix, it caused further limited diffusion of nutrients and $\mathrm{CO}_{2}$ into the

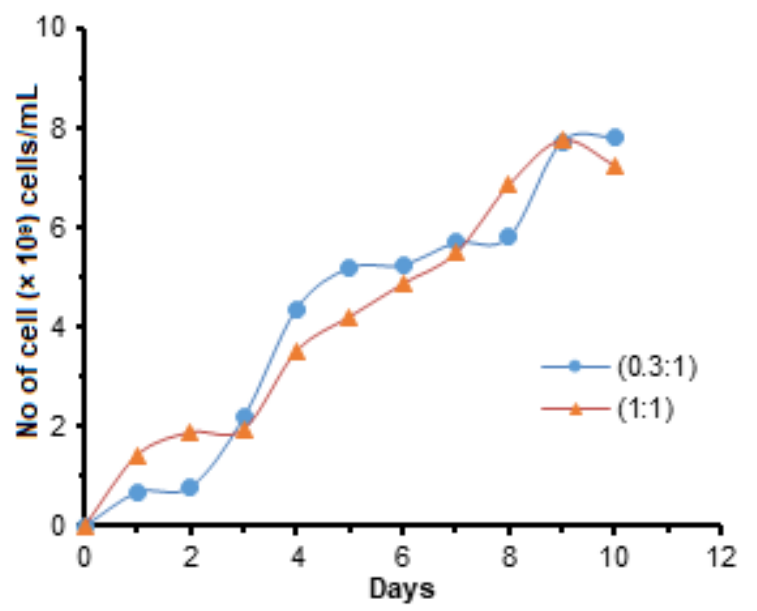

Fig 2. Growth performance of immobilized microalgae at different ratio of combination matrix of SA and CA beads. Thus, the growth of cells in the combination matrix of SA and CA was adversely affected. SA and CA have different characteristics that can limit the effectiveness of this combination system [22]. CA does not dissolve in water and is fibrous, while SA can easily dissolve in water. Thus, the combination of SA and CA does not impart much effect on the growth of the microalgae cell in the matrix, even at different volumetric ratios. The growth of microalgae in both of volumetric ratios started to decrease at day 10 . The same trend was observed from microalgae immobilized in SA for the volumetric ratio of 1:1, where the number of cells decreased after day 9.

\section{Growth Performance of Immobilized Microalgae Using a Combination of Sodium Alginate and Sodium Carboxymethylcellulose}

The growth curve of immobilized microalgae for the matrix combination of SA and sodium carboxymethyl cellulose (CMC) at volume ratios of $0.3: 1$ and $1: 1$ is shown in Fig. 3. The number of cells for both volumetric ratios did not differ much between day 1 until day 8 . However, after day 9 , the cell number slightly decreased for the ratio $1: 1$ and gradually increased for $0.3: 1$. The volumetric ratio of $0.3: 1$ gave the highest number of cells at $8.70 \times 10^{9} \mathrm{cells} / \mathrm{mL}$ at day 10 . This result proves that the volumetric ratio of $0.3: 1$ is more suitable for the growth of microalgae cells when SA was combined with CMC.

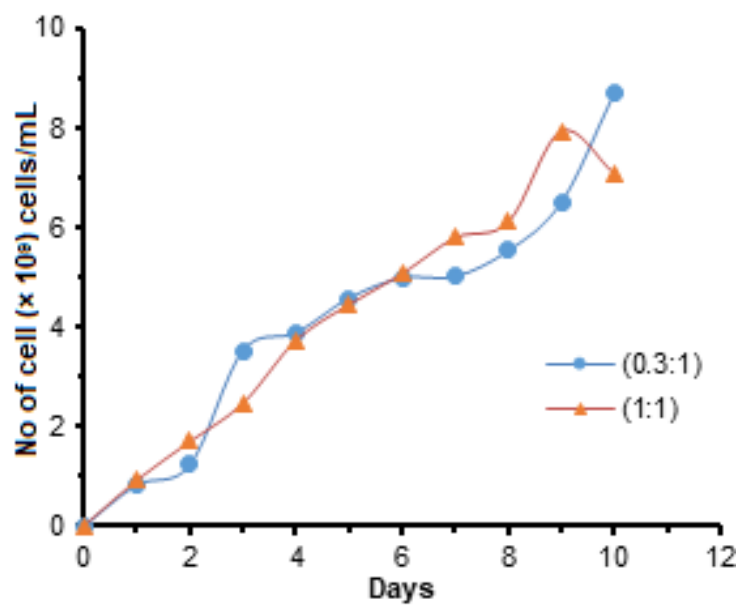

Fig 3. Growth performance of immobilized microalgae at different ratio of combination matrix of SA and CMC 
As reported by $\mathrm{Abu}$ Sepian et al. [22], the combination of SA and CMC performed better and yielded a higher number of cells compared to using SA alone as the encapsulation material. This finding may be due to the small resistance for the mass transfer of nutrients towards the cells. In addition, the large inner space of microalgae beads may have supported the higher number of cells inside the immobilized microalgae beads. Based on the results, it was verified that the matrix system of SA and CMC could enhance growth of microalgae by creating layers of membrane in the beads.

\section{Growth Performance of Immobilized Microalgae Using Combination of Sodium Alginate, Calcium Alginate, and Sodium Carboxymethylcellulose}

Fig. 4 shows the combination matrix system for SA, $\mathrm{CA}$, and $\mathrm{CMC}$ for the volumetric ratios $0.3: 1$ and 1:1. The number of cells of immobilized microalgae with volumetric ratio 1:1 was higher compared to 0.3:1 until day 6. However, the number of cells for the volumetric ratio $0.3: 1$ started to exceed that in the volumetric ratio 1:1 after day 6 , resulting in the highest immobilized growth on day 10 for the volume ratio $0.3: 1\left(8.55 \times 10^{9}\right.$ cells $\left./ \mathrm{mL}\right)$. Whereas, the cell number for volumetric ratio of $1: 1$ declined to $7.29 \times 10^{9}$ cells $/ \mathrm{mL}$ at day 10 .

Table 1 shows the comparison of the number of cells between the best volume ratios obtained from the previous section. It is apparent that the volume ratio of 0.3:1 for combination matrix systems of SA and CMC gave the highest number of cells $\left(8.70 \times 10^{9}\right.$ cells $\left./ \mathrm{mL}\right)$ at day 10 of cultivation compared to the SA, CA and CMC combinations at $8.55 \times 10^{9} \mathrm{cells} / \mathrm{mL}$. This was possibly the result of an unfavorable combination of the three matrices, due to the hydrophilic characteristic of CA [22]. As mention by Johnston et al. [24], although the hydrophilic characteristics of CA may have limited the mass transfer, the addition of sodium carboxymethyl cellulose would allow free movement of microalgae cell inside the beads. This is due to the larger space within the microalgae beads that increased mass transfer [22]. This phenomenon explains the higher number of cells produced for the SA and CMC combination as compared to SA and CA.

The growth performance of immobilized cells in SA matrix alone was different as compared to other matrix systems assessed in this study. The number of cells $\left(8.30 \times 10^{9}\right.$ cells $\left./ \mathrm{mL}\right)$ in SA was higher at a volume ratio of 1:1 at day 9 of cultivation. This observation contradicted a previous study by Lam and Lee, [17], which stated that SA alone has a better growth performance. However, the growth of microalgae appeared more favorable in CMC as compared to SA, as the number of cells increased after day 9 for the volume ratio of $0.3: 1$.

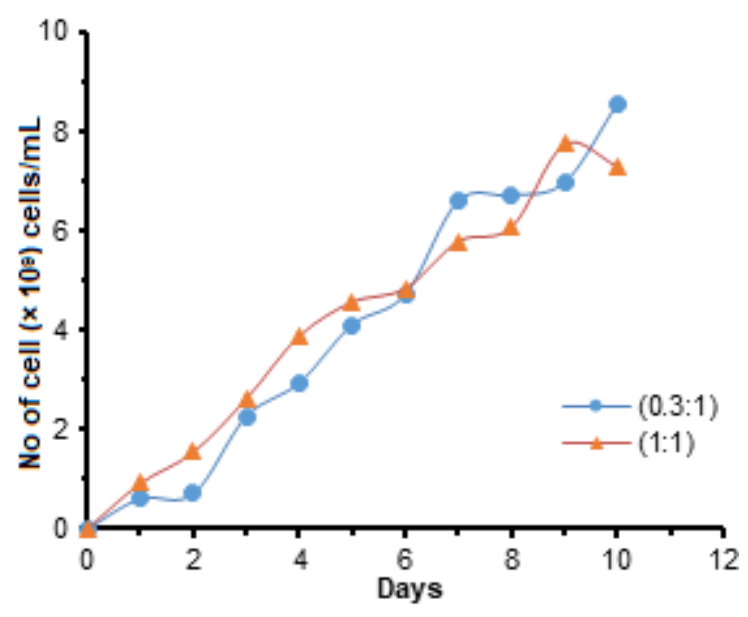

Fig 4. Growth performance of immobilized microalgae at different ratio of combination matrix of SA, CA and CMC

Table 1. Comparison number of cells for the best volumetric ratio for each matrix of microalgae

\begin{tabular}{lclc}
\hline Matrices & Volumetric ratio (matrices : microalgae) & Day & Number of cells (cells/mL) \\
\hline SA & $1: 1$ & 9 & $8.30 \times 10^{9}$ \\
SA + CA & $0.3: 1$ & 9 & $7.75 \times 10^{9}$ \\
SA + CMC & $0.3: 1$ & 10 & $8.70 \times 10^{9}$ \\
SA + CA + CMC & $0.3: 1$ & 10 & $8.55 \times 10^{9}$ \\
\hline
\end{tabular}




\section{Lipid Production of Immobilized Cell}

The yield of the produced oil was affected by a different matrix system, as revealed by the varying percentages of the recovered oils. Table 2 shows that the highest of the yield of oil extracted from C. vulgaris biomass was SA at $46.00 \%$ using the volume ratio $0.3: 1$, followed by the combinations, $\mathrm{SA}+\mathrm{CA}+\mathrm{CMC}, \mathrm{SA}+\mathrm{CA}$, and SA + CMC corresponding to 43.00, 41.19, and $40.38 \%$, respectively. However, lipid production for a volume ratio of $1: 1$ was $44.43 \%$, achieved using the combination of matrix systems of SA + CA + CMC. This was followed by the matrix systems SA + CMC and SA that yielded lipids at 41.19 and $38.43 \%$, respectively. In contrast, the lowest yield of oil was obtained in the matrix system SA + CA that corresponded to $30.76 \%$.

Lipid extraction using SA at a volume ratio of $0.3: 1$ was found to be most effective than the combined matrix systems. This result is similar to the research done by Hameed and Ebrahim [21], where higher yields were achieved for the 0.3:1 volume ratio of SA after day 10 in the growth medium. This observation might be due to the physical characteristics of other matrices which impeded their ability to extract the oil. In addition, the chlorophyll produced from microalgae in immobilized cells was higher when using just SA as a matrix [25].

When the SA was combined with other matrices to extract the oil, the yield of the oil extracted was reduced. This observation was similar to Lam and Lee [17], where oil recovery efficiency was higher in the single matrix. A possible cause for this trend when using combination matrices may be due to changes in the physical properties of these matrices, i.e., polarity and viscosity, that interfered the process of extracting the oil, as compared to the that when using the pure SA matrix. The observation in this study, however, was the opposite of the study by Abu Sepian et al. [22], which stated that the total amounts of lipid obtained from mixed matrices with SA yielded significantly different amounts of lipid. However, the combination matrix systems SA + CA + CMC of volume ratio 1:1 has a higher percentage of oil yield at $44.43 \%$. The combination of matrix systems still can be used as long as it is implied at appropriate proportions of media in order to achieve the high yield of lipid extraction.

Table 2 shows the result for lipid production in the free cell culture that corresponded to $42.57 \%$. By comparing the oil yield between the immobilized method and free cell culture, it was clearly shown that the percentage of oil recovery was slightly different when SA was used as the matrix at the 0.3:1 volume ratio. Based on the previous study by Feng et al. [26], the amount of lipid for free cell culture was lower compared to the immobilization of cells in SA at a volume ratio of $0.3: 1$. This is because of the organic carbon within the system was insufficient to support the growth of $C$. vulgaris over a long period for the production of lipid [26]. By using the immobilization method, the results showed higher lipid production was possible, as the immobilized microalgae beads have grown to stationary phase. Hence, the beads were easily harvested without involving a huge amount of energy input [17]. In addition, the cultivation process of free cell culture can be

Table 2. Lipid production by C. vulgaris with different ratio and different matrix systems

\begin{tabular}{lcccc}
\hline Matrices & $\begin{array}{c}\text { Volumetric ratio } \\
\text { (matrices: microalgae) }\end{array}$ & $\begin{array}{c}\text { Dry weight of lipid } \\
(\mathrm{g})\end{array}$ & Yield of oil (\%) & $\begin{array}{c}\text { Number of cells } \\
\left(\times 10^{9} \text { cells } / \mathrm{mL}\right)\end{array}$ \\
\hline Free cell culture & $0.3: 1$ & 0.0298 & 42.57 & - \\
SA & $1: 1$ & 0.0322 & 46.00 & 7.76 \\
& $0.3: 1$ & 0.0269 & 38.43 & 8.29 \\
SA + CA & $1: 1$ & 0.0288 & 41.19 & 7.81 \\
& $0.3: 1$ & 0.0215 & 30.76 & 7.74 \\
SA + CMC & $1: 1$ & 0.0283 & 40.38 & 10.47 \\
SA + CA + CMC & $0.3: 1$ & 0.0288 & 41.19 & 7.93 \\
& $1: 1$ & 0.0301 & 43.00 & 8.55 \\
\hline
\end{tabular}

Nur Hanani Rushan et al. 
easily contaminated, as well as being quite difficult for maintaining the growth of microalgae, hence affecting the amount of lipid produced. Therefore, the immobilization method might be the best method for producing oil as compared to free cell culture.

\section{Fatty Acid Methyl Ester (FAME) Composition}

The fatty acid methyl ester (FAME) composition for the C. vulgaris of different matrix systems was analyzed using gas chromatography mass spectrometry (GC-MS Agilent $7890 \mathrm{~N}$ ). The FAME composition of the biodiesel produced by experimental treatments is shown in Table 3. The quality of the biodiesel depends on the composition of FAME, and the amount of FAME produced can invariably be affected by the amount of lipid produced. The FAME profile in C. vulgaris cells mainly consisted of palmitic acid (C16:0), stearic acid (C18:0), oleic acid (C18:1), linoleic acid (C18:2), and linolenic acid (C18:3). A study by Lam and Lee [17], reported a similar finding where the percentage of saturated fatty acid (C16:0 and C18:0) from C. vulgaris was higher than unsaturated fatty acid (C18:1, C18:2 and C18:3).

In addition, it was found that lipid extracted from immobilized microalgae biomass has a high potential for biodiesel production due to the similar FAME profile as other oil-bearing crops. This is shown in Table 3, where the amount of total FAME of immobilized biomass was comparable to that obtained in the free cell culture. The reason behind this can be explained by the free cell culture having a higher energy consumption, and the cell of microalgae can be easily damaged. This can be associated with the longer retention required by the free cell culture method for the sedimentation of cells during harvesting as compared to the immobilized method [15]. Whereas, in the immobilization method, microalgae cells can be easily separated without resorting to a large energy input. The study has shown that the total FAME from immobilized biomass of SA + CA + CMC (1:1) was the highest $(149.20 \mathrm{mg} / \mathrm{g} \mathrm{DW})$ as compared to total FAME in the free cell culture.

The length of the carbon chain and degree of unsaturation are the important characteristics of a good quality of biodiesel [27-28]. Table 3 shows the total saturated fatty acid (SFA) being predominant from the immobilized cell system except for SA + CA (1:1). An opposite trend was seen for the free cell culture biomass in which the total unsaturated fatty acid (UFA) amount (72.06 mg/g DW) was higher compared to total SFA (51.55 mg/g DW). However, according to the European regulation (EN 14213 and EN 14214), more than 12\% of linolenic acid (C18:3) did not indicate good quality biodiesel [28]. Good quality biodiesel should have a high content of oleic acid (C18:1), which can increase the oxidative stability for longer storage of fuel [29-30]. Thus, immobilized biomass from immobilized cells of $\mathrm{SA}+\mathrm{CA}+\mathrm{CMC}(1: 1)$ and SA + CA (0.3:1) can be good potential candidate for biodiesel production since the FAME compositions were able to meet the standard of European regulation for transportation uses [28].

Table 3. Fatty acid methyl ester composition (FAME) of C. vulgaris for different matrix systems

\begin{tabular}{|c|c|c|c|c|c|c|c|c|c|}
\hline \multirow{3}{*}{ Fatty acid methyl ester } & \multicolumn{9}{|c|}{ Composition of fatty acid (mg/g DW) } \\
\hline & \multicolumn{2}{|c|}{ SA } & \multicolumn{2}{|c|}{$\mathrm{SA}+\mathrm{CA}$} & \multicolumn{2}{|c|}{$\mathrm{SA}+\mathrm{CMC}$} & \multicolumn{2}{|c|}{$\mathrm{SA}+\mathrm{CA}+\mathrm{CMC}$} & \multirow{2}{*}{$\begin{array}{l}\text { Free cell } \\
\text { culture }\end{array}$} \\
\hline & $0.3: 1$ & $1: 1$ & $0.3: 1$ & $1: 1$ & $0.3: 1$ & $1: 1$ & 0.3:1 & $1: 1$ & \\
\hline Palmitic acid (C16:0) & 42.54 & 38.88 & 38.58 & 25.47 & 32.64 & 37.62 & 25.54 & 77.74 & 26.91 \\
\hline Stearic acid (C18:0) & 32.55 & 47.66 & 37.73 & 32.31 & 35.05 & 36.80 & 36.77 & 39.76 & 24.64 \\
\hline Oleic acid (C18:1) & 15.32 & 11.33 & 14.55 & 24.35 & 21.23 & 17.98 & 28.72 & 16.59 & 22.03 \\
\hline Linoleic acid (C18:2) & 11.87 & 3.55 & 19.44 & 15.94 & 9.31 & 10.86 & 16.20 & 8.23 & 22.88 \\
\hline Linolenic acid (C18:3) & 27.61 & 30.18 & 11.60 & 27.85 & 32.22 & 17.59 & 15.84 & 7.15 & 27.15 \\
\hline Total SFA & 75.09 & 86.54 & 76.31 & 57.78 & 67.69 & 74.42 & 62.31 & 117.50 & 51.55 \\
\hline Total UFA & 54.80 & 45.06 & 45.59 & 68.14 & 62.76 & 46.43 & 60.76 & 31.97 & 72.06 \\
\hline Total FAME & 129.89 & 131.60 & 121.90 & 125.92 & 130.45 & 120.85 & 123.07 & 149.20 & 123.61 \\
\hline
\end{tabular}

Nur Hanani Rushan et al. 


\section{- CONCLUSION}

The study found that the employment of the combined matrix systems affected the number of cells as well as the amount of fatty acid produced. In this study, CMC gave a huge impact on SA since the number of cells increased after day 9 of cultivation for the combination matrix of SA and CMC. However, the extraction of oil from C. vulgaris using SA for the volume ratio 0.3:1 showed better results with an oil yield percentage of $46 \%$, as compared to other matrix studied systems, namely SA $+\mathrm{CA}+\mathrm{CMC}$ (43.00\%), SA+ CA (41.19\%) and SA + CMC (40.38\%). Fatty acid profile produced by the C. vulgaris biomass indicates it is a good candidate for biodiesel production. Percentages of saturated fatty acids (C16:0 and C18:0) were higher than the unsaturated fatty acids (C18:1, C18:2 and C18:3). Hence, it was proven that the immobilization method was better than free cell culture for producing fatty acids, as the former yielded higher amounts of fatty acid for SA + CA + CMC (1:1) which is $149.20 \mathrm{mg} / \mathrm{g}$ DW as compared to the free cell culture of $123.61 \mathrm{mg} / \mathrm{g}$ DW.

\section{- ACKNOWLEDGMENTS}

The authors would like to acknowledge the financial support for this work from Universiti Malaysia Pahang (UMP) internal grant (RDU150396 and RDU180352) and

UMP Postgraduate Research Grants Scheme (PGRS180382) for supporting this research.

\section{- REFERENCES}

[1] Onay, M., Sonmez, C., Oktem, H.A., and Yucel, M., 2016, Evaluation of various extraction techniques for efficient lipid recovery from thermo-resistant microalgae, Hindakia, Scenedesmus and Micractinium species - Comparison of lipid extraction methods from microalgae, Am J. Anal. Chem., 7 (2), 141-150.

[2] Singh, N.K., and Dhar, D.W., 2011, Microalgae as second generation biofuel. A review, Agron. Sustainable Dev., 31 (4), 605-629.

[3] Singh, M., Shukla, R., and Das, K., 2013, "Harvesting of Microalgal Biomass" in Biotechnological Applications of Microalgae: Biodiesel and Value
Added Products, $1^{\text {st }}$ ed., Eds., Bux, F., CRC Press, USA, 77-87.

[4] Amin, S., 2009, Review on biofuel oil and gas production processes from microalgae, Energy Convers. Manage., 50 (7), 1834-1840.

[5] Brennan, L., and Owende, P., 2010, Biofuels from microalgae-A review of technologies for production, processing, and extractions of biofuels and co-products, Renewable Sustainable Energy Rev., 14 (2), 557-577.

[6] Moreno-Garrido, I., 2008, Microalgae immobilization: Current techniques and uses, Bioresour. Technol., 99 (10), 3949-3964.

[7] Priyadarshani, I., and Rath, B., 2012, Commercial and industrial applications of micro algae - A review, J. Algal Biomass Util., 3(4), 89-100.

[8] Griffiths, M.J., Dicks, R.G., Richardson, C., and Harrison, S.T.L., 2011, "Advantages and Challenges of Microalgae as a Source of Oil for Biodiesel" in Biodiesel - Feedstocks Processing Technologies, Eds., Stoytcheva M., and Montero, G., IntechOpen, 177200.

[9] Månsson, S., 2012, Cultivation of Chlorella vulgaris in nutrient solution from greenhouse tomato production, Thesis, Department of Horticulture, Swedish University of Agricultural Sciences, 32.

[10] Barros, A.I., Gonçalves, A.L., Simões, M., and Pires, J.C.M., 2015, Harvesting techniques applied to microalgae: A review, Renewable Sustainable Energy Rev., 41, 1489-1500.

[11] Ramaraj, S., Hemaiswarya, S., Raja, R., Ganesan, V., Anbazhagan, C., Carvalho, I.S., and Juntawong, N., 2015, "Microalgae as an Attractive Source for Biofuel Production" in Environmental Sustainability - Role of Green Technologies, Eds., Thangavel, P., and Sridevi, G., Springer India, 129-157.

[12] Pittman, J.K., Dean, A.P., and Osundeko, O., 2011, The potential of sustainable algal biofuel production using wastewater resources, Bioresour. Technol., 102 (1), 17-25.

[13] Xu, L., Guo, C., Wang, F., Zheng, S., and Liu, C.Z., 2011, A simple and rapid harvesting method for 
microalgae by in situ magnetic separation, Bioresour Technol., 102 (21), 10047-10051.

[14] Singh, G., and Patidar, S.K., 2018, Microalgae harvesting techniques: A review, J. Environ. Manage., 217, 499-508.

[15] Ahmad, A.L., Yasin, N.H.M., Derek, C.J.C., and Lim, J.K., 2014, Comparison of harvesting methods for microalgae Chlorella sp. and its potential use as a biodiesel feedstock, Environ. Technol., 35 (17), 22442253.

[16] Al Hattab, M., Ghaly, A., and Hammoud, A., 2015, Microalgae harvesting methods for industrial production of biodiesel: Critical review and comparative analysis fundamentals of renewable energy and applications, J. Fundam. Renewable Energy Appl., 5 (2), 1000154.

[17] Lam, M.K., and Lee, K.T., 2012, Immobilization as a feasible method to simplify the separation of microalgae from water for biodiesel production, Chem. Eng. J., 191, 263-268.

[18] Krajewska, B., 2004, Application of chitin- and chitosan-based materials for enzyme immobilizations: A review, Enzyme Microb. Technol., 35 (2-3), 126-139.

[19] Moreno-Garrido, I., Campana, O., Lubián, L.M., and Blasco, J., 2005, Calcium alginate immobilized marine microalgae: Experiments on growth and short-term heavy metal accumulation, Mar. Pollut. Bull., 51 (8-12), 823-829.

[20] Arica, M.Y., 2000, Immobilization of polyphenol oxidase on carboxymethylcellulose hydrogel beads: Preparation and characterization, Polym. Int., 49 (7), 775-781.

[21] Hameed, M.S.A., and Ebrahim, O.H., 2007, Biotechnological potential uses of immobilized algae, Int. J. Agric. Biol., 9 (1), 183-192.

[22] Abu Sepian, N.R., Mat Yasin, N.H., Zainol, N.,
Rushan, N.H., and Ahmad, A.L., 2019, Fatty acid profile from immobilised Chlorella vulgaris cells in different matrices, Environ. Technol., 40 (9), 11101117.

[23] Eroglu, E., Smith, S.M., and Raston, C.L., 2015, "Application of Various Immobilization Techniques for Algal Bioprocess" in Biomass and Biofuels from Microalgae. Biofuels and Biorefinery Technologies, Vol. 2, Eds., Moheimani, N., McHenry, M., de Boer, K., and Bahri, P., Springer, Cham, 19-44.

[24] Johnston, D., Kumar, P., Yahya, E., Toit, L.C., and Pillay, V., 2013, Modulation of the nano-tensile mechanical properties of co-blended amphiphilic alginate fibers as oradurable biomaterials for specialized biomedical application, J. Mech. Behav. Biomed. Mater., 23, 80-102.

[25] Kaparapu, J., and Rao, G.M.N., 2016, Applications of immobilized algae, J Algal Biomass Util., 7 (2), 122-128.

[26] Feng, Y., Li, C., and Zhang, D., 2011, Lipid production of Chlorella vulgaris cultured in artificial wastewater medium, Bioresour. Technol., 102 (1), 101-105.

[27] Griffiths, M.J., and Harrison, S.T.L., 2009, Lipid productivity as a key characteristic for choosing algal species for biodiesel production, J. Appl. Phycol., 21 (5), 493-507.

[28] Knothe, G., 2006, Analyzing biodiesel: Standards and other methods, J. Am. Oil Chem. Soc., 83 (10), 823-833.

[29] Knothe, G., 2005, Dependence of biodiesel fuel properties on the structure of fatty acid alkyl esters, Fuel Process. Technol., 86 (10), 1059-1070.

[30] Rashid, U., Anwar, F., Moser, B.R., and Knothe, G., 2008, Moringa oleifera oil: A possible source of biodiesel, Bioresour. Technol., 99 (17), 8175-8179. 